\title{
The Discreet Community Hugo von Hofmannsthal's Der Schwierige
}

(Published in Arcadia 46.1, 2011)

In his comedy Der Schwierige, Hugo von Hofmannsthal imagines a community without chauvinism. The play's main protagonist Count Hans Karl Bühl claims that it is indecent to speak, and even to have experiences, and proposes an attitude of humility that would in effect entail the individual's self-effacement. However, this attack on individuality as a form of insolence does not pave the way for an affirmation of any greater social or mystical whole, since such formations would run the risk of reproducing arrogance at a higher level. Once one has relinquished all claims to superiority as an individual, one cannot re-emerge as a secure member of a harmoniously unified and stable collective. The community to which the individual should surrender himself to shed his arrogance exists in a genuine manner only in the moment when all of its members abandon any presumptions about the love, admiration, and collaborative capacities of others. If its members would speak triumphantly about their connection, this community would cease to be. To sustain its mode of togetherness, its participants must remain separate and silent, discrete and discreet.

Hugo von Hofmannsthal's play Der Schwierige, a work that enjoys a relatively secure position in the literary canon, is a comedy that takes place in Viennese high society. ${ }^{1}$ These designations of genre and setting are uncontroversial. ${ }^{2}$ For the main protagonist, count Hans Karl Bühl, interaction in this milieu has become problematic for two reasons: many of his fellow men are driven by self-interests, and every attempt to reach a goal in communication with others leads to confusion and misunderstanding. The misunderstandings are exasperating, and the calculation and pursuit of advantage is brash, at least when measured against declining aristocratic standards of conduct. This too is beyond dispute among scholars. ${ }^{3}$

What has not been noted, however, is to what extent this image of a "Gesellschaft" in a particular time and place parallels the most basic definition of society 
in modern social theory. Hofmannsthal concentrates on two aspects of human interaction: the motives and actions of single individuals ("Absichten"), and the unpredictable and frequently less than optimal outcome of their actions ("Konfusionen"). ${ }^{4} \mathrm{He}$ focuses, then, on intentions and unintended consequences. It is on the basis of this formula that one can say that Hofmannsthal shares a set of assumptions with a range of social theorists.

Modern society has been said to consist of multiple self-interested agents who pursue particular ends in competition with others. The unintended outcomes of their individual actions can be beneficial to them, as Adam Smith famously asserted, or harmful. ${ }^{5}$ Regardless of the assessment of the outcomes, however, society is viewed as a dynamic complex of wills, where the behavior of the aggregate, "das Ganze," ${ }^{\circ}$ stands in a certain relation to the behavior of the individuals. ${ }^{7}$ In the guise of "Absichten" and "Konfusionen," this is also the underlying concept of what constitutes society in Der Schwierige. The play may be a nostalgic look at the disintegrating Austrian nobility and a satire of an emerging “"modern' approach to life," but precisely for this reason it admits the prevalence of a pushy individualist ethos in society. ${ }^{8}$ Hofmannsthal's comedy is written from within a distinctly modern "social imaginary": principles such as "hierarchic complementary" have been replaced by a vision of sharply contoured individuals, driven by intentions, interacting with one another and generating unanticipated beneficial or harmful results in the process. ${ }^{9}$

As the title indicates, the comedy's hero, the count, is a difficult man who does not want to participate in the "absichtvolle Welt" that the play puts on the stage. ${ }^{10}$ To be animated by intentions is supposedly foreign to him. In the company of "overpurposeful" men, he is a "Mann ohne Absicht." ${ }^{, 11} \mathrm{He}$ also wishes to remove himself from 
the confusion that ensues once individuals seek to realize their plans among each other. The two tendencies are closely related: if one strives to attain particular ends in the volatile field of human communication and interaction, to move other people in a certain way and thereby achieve certain favorable results, one is, in Hans Karl's judgment, bound to fail. This suggests that the count is in fact of a piece with the world he deplores. The confusions that arise from social interactions are only seen as deviation and decay only from the perspective of someone who conceives of action and speech as the realizations of his or her intentions. Hans Karl may have rid himself of narrow intentions, but his despair at mix-ups and apparent disorder is nonetheless premised on this instrumentalist understanding of individual action. While the difficult man does reflect critically upon modern society, he may still be captive to its notions of what constitutes human agency. Der Schwierige presents the modern social world as a dynamic arrangement of multiple individual wills, the aggregate behavior of which escapes the control of any one agent. In the play, these unavoidable disjunctions between intentions and consequences become a source of amusement. Around Hans Karl, a series of very determined characters set themselves ambitious goals (material security, marital bliss, fame) and then go on to fail briskly and vigorously once they encounter others, on whose attitudes and choices their success ultimately depends. The play bundles plot lines of well-deserved disappointment. ${ }^{12}$ There is the intrusive new butler who does not secure lifelong employment, the overconfident young man who does not succeed in marrying, the academic parvenu who receives no recognition, and the suave Prussian bully who is rebuffed by the women he sets out to conquer. If society is defined in terms of the outcomes of self-interested individual action, it lends itself to comedic representation, at 
least in so far as these outcomes tend to frustrate purposive human activity. It is in this specific, almost technical sense that comedy can be regarded as the premier genre of the social, to draw on Hofmannsthal's cryptic statement "das erreichte Soziale: die Komödien."13 What could count as alienation, canonically defined as the loss of human control over the effects of human agency in society,${ }^{14}$ can also be enjoyed, at least to the observer who remains sufficiently detached to laugh at rather than be touched by failure and disappointment. ${ }^{15}$ Following Hofmannsthal's definition of comedy as the genre of the “social," one can even call Der Schwierige a meta-comedy. As Peter Szondi points out, the play thematizes the trouble with action in modern society by inserting a character the count - that comments upon the very disconnections that the play exploits for comic effect. $^{16}$

Hofmannsthal's play represents society in a way that is broadly consistent with modern social theory: multiple agents, identified as centers of "freier Willkür," work to realize their intentions. ${ }^{17}$ But can one discern a different conception of men and their interaction in the play? What would be the alternative to the dominant logic of society? Is there another kind of human collective than the compound of individual interest?

Two superficially plausible but ultimately inadequate answers can be dealt with here. The first is misanthropy, the principled withdrawal from all human affairs. In his final words, Hans Karl voices a radical response to a world of insufferably brazen individuals and inevitable confusions. Yet the rejection of all human contact would, of course, also eliminate any possible counter-conceptions of community. The misanthrope simply wants to be left alone. Nor can the problem of society, or the problem that is society, be remedied by means of successfully coordinated collective action, unhampered 
by any confusion in the sense of misunderstandings and conflicting purposes. The transparency of a perfect alliance of several agents integrated into one social super-agent cannot be the aim, since that would merely reproduce the problem of intention and will on the level of the collective. That this alliance could take the exalted form of the simultaneous dissolution and incorporation of all individual wills into one mythic world will - the "Willen des Lebens" 18 - does not make a difference. Neither the absence of society nor the transcendence of its self-generated difficulties can genuinely address its fundamental character. In fact, misanthropy and perfect (or mythic) union of matching purposes are shown to coincide in the play; they both entail forms of isolation.

A more satisfying answer to the question of a human collective beyond the energies and mechanisms of modern society can be found in the notion of a discreet community. This discreet community is nowhere explicitly defined or fought for in the play; if it were defined, it would just be another individual or collective project. Instead, the discreet community does not give itself a name, because it does not function as an entity that could announce itself and take measures to ensure its survival and expansion. It persists only insofar as its participants are cautious enough not to declare its stable existence, or insofar as its participants abstain from claiming membership in some enduring group. The medium of this community is discretion; it is left unsaid. ${ }^{19}$

Hofmannsthal's society is a configuration of individual wills and possesses an atomistic constitution. His play is populated by a number of solitary figures. These solitary figures are often those individuals who are the most garrulous: it is their incessant talking rather than their silence that reveals their distance from others. Their very confidence about the ways of the world and the minds of people, in combination with 
their predilection for self-assured pronouncements on these matters, blocks them from noting the difficulties that interaction with actual others typically bring. The new butler Vizenz arrives at the beginning of the play and believes that he can quickly survey the situation in the household. He thinks that he can determine the habits and wishes of his future master, manipulate the conditions as he pleases, and set up a comfortable life. Speaking of Hans Karl, he states: "In einem Monat wickel ich ihn um den Finger." ${ }^{20}$ Hans Karl's nephew prides himself on his manly decisiveness and his sense of the course and meaning of the world. In mini-lectures on himself, his plans and the state of things in general, he delivers statement after statement, unburdened by any self-insight: "Ich denk' über alles nach, und mach' mir immer zwei Kategorien”; “Ich behalte alles immer in der Hand." ${ }^{21}$ A more peripheral figure, such as the famous professor who wants entry into high society, is a case study in conceit. Finally, the visiting baron Neuhoff declares how Helene will yield to his magnetism - "Sie werden mich heiraten, weil Sie meinen Willen spüren in einer willenlosen Welt" - just before she snubs him. ${ }^{22}$ The play thus presents a veritable catalogue of vices and errors such as vanity, excessive confidence, hasty judgments, and conflation of opinion and fact. All of these attitudes in one way or another serve to desensitize individuals to the presence of others with unknown desires and directions. Under the spell of their self-images, these men fail even as self-interested agents, who would have to take others into account at least for purely strategic reasons. Rivalries and complications, they believe, should be negated rather than negotiated. The play presents these figures ironically: there are gaps between their high opinions of their craftiness, experience, stature or will power, and their actual capacities and achievements, and these gaps lead to failures for "those who exhibit the most resolute 
designs [in Der Schwierige] meet with least success. ${ }^{.23}$ But these characters are also lonely, for their self-congratulatory attitudes isolate them from their surroundings. While making grandiose claims about themselves and the world they inhabit, they do not take the possible viewpoints and actions of others into account, viewpoints that may be admiring or critical, actions that may be supportive or undermining. Nothing they say or do is submitted to others (although these others may well come to obstruct their plans). Uninterrupted self-praise preempts the recognition and response that could come from someone else. Isolation is the specifically social meaning of their high opinion of themselves.

Hans Karl perceives the ludicrousness of self-regard. Towards the end of the play, he becomes increasingly frustrated and his final assertions are his least conciliatory ones. What he rejects in his fellows is then the attitude of "rasende Verliebtheit in sich selbst. ${ }^{24}$ Regardless of what specific practice or phenomenon he criticizes, extreme selflove is presented as a negative value, the attitude that should always be shunned, or at the very least not publicly displayed to any degree by men of dignity and integrity. Yet the counter-position that Hans Karl gestures toward in this final outburst is only another form of solitary life. Angered or even disgusted with endemic egocentrism, he argues for withdrawal from society. The difficult man is, as prominent commentators have argued, a misanthrope..$^{25}$

What counts as a manifestation of "rasende Selbstverliebtheit"? The simple answer is that, to Hans Karl, every act of expression falls in the category of human indecency: "alles, was man ausspricht, ist indezent. ${ }^{2{ }^{26}}$ Even to experience anything, to encounter the world with the senses, constitutes an act of shameful, even obscene self- 
love, and should therefore be avoided. It is this radical stance that makes Hans Karl a misanthrope: rather than take words in his mouth, he exclaims, he would crawl into a primitive hut, somewhere far away from other members of the human species. Yet given the scope of his dislike, such self-removal from society would hardly be enough: his misanthropic program is so extreme as to lead to complete silence, and even to an end to life, since living must mean experiencing, which he has also put a ban on. It is not quite enough to leave the city behind and live alone in nature; one has to disappear completely as a being.

The figures in Der Schwierige either separate themselves from others, or say that they would want to achieve such a separation. We see men who in their self-adulation close themselves off to the perspectives of their fellows, and we hear Hans Karl's denunciation of all speech and experience, which he views as so many emanations of outrageous self-love. Against the hubris of those who lecture about their own cunning, mastery or erudition stands the condemnation of all talk; against exaggerated selfassertion stands total self-erasure.

It is unclear if the play ratifies any of the positions outlined above. Of course, excessive self-regard is not a position, but a flaw, and like other comedies, $\mathrm{Der}$ Schwierige exposes human follies. But in the comedic tradition on which Hofmannsthal builds, principled misanthropy also represents a flaw, and is typically subjected to revelatory ridicule. While Hans Karl is a hero, a deeply sympathetic character "admired by all," and, as such, a remarkable addition to the literary history of misanthropy, his final declaration does not have to be understood as the culminating thesis of the entire work. ${ }^{27}$ Instead, the play offers us a glimpse of what a genuine community might be like, 
of how relationships among individuals are possible and can be sustained beyond the mirroring conditions of self-love and disgust with self-love. This community - discreetly sketched out or hinted at in conversation rather than presented in the semi-lecture form preferred by so many of the characters - provides an antidote to the excesses of selfpraise and denunciation. Its emergence is also inseparable from the practice of politeness, or the art of keeping quiet.

The remedy for the scandalous overestimation of one's own person is modesty, the ability and willingness to be unassuming in social contexts. One traditional site of such modesty is the conversation, understood as the practice of moderate self-effacement for the benefit of a discursive back and forth among interlocutors. ${ }^{28}$ As a particular practice, conversation has reciprocity as its grounding structural requirement, and it demands that participants curtail their monologues to make space for the contributions of others. ${ }^{29}$ In Hofmannsthal's Der Schwierige, old Altenwyl is the one who voices this condition: "nicht selbst perorieren, wie ein Wasserfall, sondern dem andern das Stichwort bringen." ${ }^{30}$ No one should give long lectures in the salon, because conversations preprogrammed by one participant are not conversations at all. ${ }^{31}$ Conversations demand rather that one relinquish one's resolute intentions about what should happen and instead remain sufficiently receptive to the "subtle cues" of others. ${ }^{32}$ In an aphorism in Menschliches-Allzumenschliches, Friedrich Nietzsche remarks that meandering conversations among several interlocutors cannot be forced in a particular direction with less than comic results; one has to follow the flow of the conversation rather than seek to impose one's preferred logic on it. ${ }^{33}$ The conversation is therefore a medium in which "Absichten" are deflected. Looking at the play, it is perhaps more accurate to say that 
people powered by strong intentions tend to ruin conversations with their long-winded presentations. Energetic, enterprising people may find it difficult to converse because, intent on implementing their already worked-out plans, they are blind to or impatient with the associative leaps of talk. In contrast, Hans Karl, as Maximilian Bergengruen notes, is especially permeable or "suggestible" to the impulses of others. ${ }^{34}$

In Der Schwierige, modesty or humility, as practiced in conversation, is entwined with community. Defined in a minimal fashion as the being-together of singular individuals, as the "inclining of one toward the other," community is only possible among people who are in some way humble. ${ }^{35}$ The lack of humility is coterminous with disregard for others and effective indifference to the recognition that can only come from them - or rather the conversational distractions that can only occur with them. Only those who are humble, who cut down on lecturing and do not pre-empt the variable impulses that others may provide in communication, are capable of remaining in a community; only they are truly open to others, which means distractable by others in conversation. But if humility involves the acknowledgment of others in their separateness and unpredictability, and the readiness to give them sufficient room, then the misanthrope would repudiate humility in the act of effacing himself. Humility comes alive in a relationship, cautiously maintained and tended to, and this relationship disappears regardless of whether an individual removes others (in the blindness of his self-love) or removes himself (in disgust with the most minimal signs of self-love).

The community that becomes possible in conversation requires a degree of humility, for no single interlocutor should dominate or direct the course of everyone's talk. Yet the resulting community of the humble and distractable must itself in some 
sense remain humble. The people coming together in conversation may regard their discourse as a wonder of smooth collaboration, but were they to announce this, the precarious process of coming-together would be denied. This may seem an abstract proposition, but it is articulated within the play, in one of the conversations between Hans Karl and Helene. Hans Karl and Helene understand each other. They share views, echo each other's formulations, and communicate their mutual sympathy. Yet they also shy away from setting up a closed circuit of reciprocal praise. Nothing is more fragile and should be handled with more hesitation than the sympathy of others as it becomes apparent in conversation:

Hans Karl: Man versteht sich mit Ihnen ausgezeichnet. Da muß man sehr achtgeben.

Helene sieht ihn an: Da muß man achtgeben?

Hans Karl: Freilich. Sympathie ist ganz gut, aber auf ihr herumzureiten, wäre doch namenlos indiskret. Darum muß man doch gerade auf der Hut sein, wenn man das Gefühl hat, sich sehr gut zu verstehen. ${ }^{36}$

The sympathetic understanding one unexpectedly encounters in another person is not an occasion for displays of self-assurance. Gestures of triumph would only disperse the signs of recognition that one must receive from someone else, and treat a possibly transient moment of grace as if it were a lasting achievement. To "ride around" on someone's praise only turns that person into a convenient vehicle for renewed self-praise. 
Through a detour, the isolation of boastfulness would then return. The sympathy one encounters must therefore be approached with great discretion: it must be left unsaid.

As critics of the concept of sympathy have pointed out, the "modest degree of unity" provided by sympathy, in which one person enters the feelings of another in a "highly self-conscious act of [...] imagination," only discloses how far men have in fact drifted apart. ${ }^{37}$ Yet Hans Karl does not greet sympathy as a weak means to do away with alienation and a first step towards perfect unity; instead, he seeks to protect sympathy's existence in its very tenuousness through heightened discretion. Emil Staiger claims that Hans Karl and Helene are already united - "sie haben nichts zu überbrücken" - and that Hans Karl creates an "Entfernung" in their conversation through artificial means ${ }^{38}$ What Staiger does not consider is that the count may also be trying to preserve something, namely the fragile community between distant individuals that appears in moments of sympathy. The "Entfernung" constitutes rather than prevents the full realization of community.

Hans Karl claims that it is indecent to speak, and even to have experiences, and proposes an attitude of humility that would in effect entail the individual's complete selfeffacement. However, this attack on individuality as a form of insolence does not pave the way for an affirmation of a union of two souls or any other greater social or mystical whole, since such formations would run the risk of reproducing blind arrogance at a higher level. All such images of union cancel out the process through which disparate interlocutors first come together but also keep apart, thereby forming a tenuous community of sympathy. Once one has relinquished all claims to superiority as an individual, and agreed to enter the unpredictable field of conversation, one cannot re- 
emerge as a secure member of a harmoniously unified group, in which each participant eternally supports the others without friction and disturbance. The conversational community to which the individual should surrender himself to shed his arrogance exists in a genuine manner only in the moment when each of its members abandons any presumptions about the love, admiration, and collaborative capacities of others. If this community would announce itself as a new unity and its members speak openly and triumphantly about their connection, it would cease to be. To sustain its mode of togetherness, its participants must remain separate and silent, discrete and discreet. In Der Schwierige, Hofmannsthal imagines a community without chauvinism. Chauvinism can emerge on all levels of human life: that of the individual, the pair, the clique, or even the entire species. In an article on Hofmannsthal and Calderón, Ernst Robert Curtius points to the depth of Hofmannsthal's wariness. If the human species celebrates itself over and above the order of all beings, it makes itself guilty of “Überhebung”: “Das Anthropozentrische,” Hofmannsthal writes, “ist auch eine Art von Chauvinismus." ${ }^{39}$ In fact, Hofmannsthal proposes that a community must be free from chauvinism to be a community at all. As soon as a community is thought of as a perfect fit of two or more individuals locked in mutual love and admiration, it no longer constitutes a community, but another version of the detached and indivisible atom. As the exchanges between Hans-Karl and Helene suggest, the moment of sympathy, in which one person is attentive and open to the life of another, is extraordinarily fragile also or primarily because of its seemingly inherent tendency to lead up to a greater and more transparent understanding. The actual joining of two individuals in confirmations of mutual love untroubled by anything external simultaneously perfects and endangers the 
forming community. A community is only a community as long as it preserves its "precarious, on-the-verge nature" that can be mistakenly viewed as the first step towards a fuller and more direct union. ${ }^{40}$

Hugo von Hofmannsthal's hero in Der Schwierige starts out as a solitary man but moves towards engagement at the end of the play. After many misunderstandings and complications, the "Lustpiel" ends happily, in conformity with the comedic tradition. ${ }^{41}$ Yet the play's middle stretch of commotion and disruption is also a space of forming something like a community. Whatever religious doctrine of marriage Hofmannsthal might have endorsed, ${ }^{42}$ his play suggests that confusion is not necessarily an obstacle to community, but perhaps an unavoidable feature of it. When the difficult man is lonely or attacks society, he seems to stand apart from others. Yet when he has united with his loved one in marriage, he is or will be beyond community, for, in the moment in which two individuals become one, and hence inseparable and indistinguishable from one another, they no longer form a community. As Wolfram Mauser points out, Hans Karl and Helene seem to disappear into a state of "elitäre Vereinzelnung" at the very end of the play. ${ }^{43}$ The relations that bind individuals together and yet also keep them apart have in this moment fallen away. In conversation with Helene, or in long reminiscences that interrupt the back and forth of a genuine conversation, Hans Karl speaks of marriage in terms of a miraculous synthesis: "zwei Menschen, die ihr Leben aufeinanderlegen und werden wie ein Mensch., ${ }^{\not 4}$ This one human being would then have the capacity for loneliness, like all other single human beings. Hans Karl and Helene are together in a more genuine way, however, in the moment this approaching harmony is disturbed. At the end of the scene, the self-important professor comes in, hunting for recognition; and 
the lovers disperse: "Sie wollen sich die Hände geben, keine Hand findet die andere." 45 This image of shared separation or of mutual fumbling captures a more authentic moment of community than Hans Karl's programmatic statement about the unity of two in marriage. The fusion or the "effervescence assembling the elements [. . .] to give rise to unity" would seem to be the ideal of any passionate community but necessarily destroys it. ${ }^{46}$ The play also shies away from any direct, climactic celebration of (marital) union in the final scene.

This sheds light on the proximity of misanthropy and marriage in Der Schwierige. Arguing that the excessive language of "Hans-Karl's 'finale" recalls the fury of Molière's misanthrope Alceste, Dorrit Cohn concludes that Hans-Karl becomes more misanthropic after he has made the decision to marry. ${ }^{47}$ In her interpretation, this development represents a "favourable turn of events" that testifies to the transforming power of love: "only after he [Hans Karl] has experienced the possibility of true communion with another human being [...] can he pass from mystic isolation to misanthropic communication. ${ }^{״ 4}$ But this close relation between impending union and misanthropic diatribe could also be adduced to support a simpler thesis: the "true communion" through which two become one can itself be a form of misanthropy, for it too can constitute a repudiation of and retreat from society. This is not an argument for society as a configuration of wills. Rather, community happens in between the busy atomism of modern society and the self-canceling harmony of "true communion," when individuals perceive and are attentive to each other but have not yet formed new cells that break off into isolation. As prominent theorists of comedy have pointed out, comic plays 
typically end with weddings, that is, they cannot continue beyond the marriage: there are no divides and disjunctions left. ${ }^{49}$

Community calls for circumspect avoidance of any strong claim to unity that would violate its existence and turn being-together into oneness. The others with whom one can form a community are forever distant, and therefore also resistant to complete integration in any settled and transparent union. Following the idea that community exists only in reciprocal acts of discretion that defer any confident announcement of unity and oneness, Hofmannsthal's play also propounds something like an argument for politeness. To be polite is first of all to take others into account: civil behavior presupposes the ability to imagine "the impact of one's own actions on others," ${ }^{50}$ that is, the ability to grasp the implications of a "symmetrische Interaktionsstruktur" in which individuals hypothetically could change places with each other. ${ }^{51}$ At the very least, manners are means to placate others or flexibly neutralize potential conflicts and thus to remain in touch. Hans Karl's demeanor agrees with this notion of politeness: he exercises discretion, for instance, by refraining from turning encounters with others into dramatic showdowns, or exploding when boasting visitors lecture him. ${ }^{52}$

As critics of politeness would insist, however, behaving politely is also a way of distancing oneself from others. Unfailingly polite people may be pleasant to spend time with, but they also seem to hide behind a surface of socially acceptable behavior. According to this more suspicious attitude, to be polite is to elide what one actually thinks, even to traffic in deception..$^{53}$ The play recognizes this crucial use of politeness too. Helene depends on good manners to protect herself by keeping others away (“die Leut' vom Hals zu halten"). ${ }^{54}$ It is not impossible to reconcile the idea of politeness as 
presupposing empathy on the one hand and as allowing for evasiveness on the other. In fact, the issue of whether politeness brings us together in mutual respect or whether it keeps us apart is a "false opposition." ${ }^{\text {55 }}$ Politeness is both the effort not to be blunt and intrusive to spare others, and not to let those others intrude; it is the way in which one may embrace strangers but also maintain a degree of estrangement. As such, politeness is a consistent practice: the caution a person offers to others should ideally be reciprocated. Speaking again in a spatial idiom, polite people draw together and simultaneously keep their distance, always "opening easy spaces for others to move." ${ }^{56}$ It follows that the discretion that Hans Karl shows with respect to others, and the manners with which Helene protects herself, are aligned. If two individuals are non-intrusive with regard to each other, then they also acknowledge their co-presence as distinct persons. The do not seek to close the divide across which they responsively communicate with each other.

The discreet community does not constitute an ideology because it appears only insofar as its participants reciprocally withdraw from any definite assertions about shared or divergent commitments. Without crystallizing as a group around a set of beliefs, the interlocutors cohere through a potentially endless sequence of acts of deference. Decorum rather than doctrine holds them together. Similarly, Der Schwierige as a comedy is not a vehicle of a particular principle or belief, but rather a humorous exemplification of how one should, in politeness, cautiously retreat from overconfident and possibly divisive statements on the world, on others, and on oneself. Figures within the play are good at declaring strong opinions on all kinds of matters, and they are all portrayed as rude or deluded. In contrast, the exquisitely polite do not parade their views, but rather seek to set up opportunities for others around them to speak. Whenever two polite individuals meet, 
the center space of the conversation is left unoccupied by lengthy speeches. A conversation may have any number of themes, but does not tolerate any definite agenda. Hofmannsthal could very well have been committed to the "ceremonial formalism" of the imperial Habsburg tradition ${ }^{57}$ or the "sacrament of matrimony,",58 and these commitments may even be articulated by characters in the play; but the discreet community that also appears and fades away cannot so easily be included in any program of restoration. Instead of trying to distill a doctrine from the practice of politeness, one should ask if any doctrine could be discretely fitted into an ongoing conversation. The speechifying characters of the play show that this does not work: editorials and sermons are too bulky for conversations.

As a play, Der Schwierige is too discreet to promote a specific ideology; it can only hint at things. If measured against the standards of polite demeanor that are indicated within the text, didacticism would be judged obtrusive. The comedy even encodes, in its plot and in its language, the comportment of discretion that can be performed in the special environment of the salon. Characters in the play may be upset with each other, but loud confrontations are scarce. When Hans Karl wants to get out of speaking in the parliament but does not say so openly to Altenwyl, this can be ascribed to his evasive behavior. Yet when Stani, the overconfident nephew, does not get a scene together with the women he desires and thinks are desirous of him, the play is simply sparing him unnecessary humiliation. As Benjamin Bennett has argued, the still young Stani is always "conveniently on the way out" of scenes and this in effect protects him, and us all, from embarrassment. ${ }^{59}$ Discretion is not only a virtue of a handful characters in 
the play, but operative in the structure of the plot. In a letter to Leopold von Andrian from 1917, Hofmannsthal himself even speaks of an ideal of "discrete Darstellung.,"60

This principle of discreet representation includes, finally, the dimension of style. Out of politeness, we adapt our speech and gestures to those we interact with, making every conversation a search for a common idiom. As a rule, however, too ornate or literary a style would be inappropriate in the fluid conversational context, oriented as it is towards an exchange of pleasant and brief replies. ${ }^{61}$ In Hofmannsthal's play, no one sets him- or herself apart entirely from the language of the others: Hans Karl uses the interjection "absolut" just as his nephew does, although they are quite different men. ${ }^{62}$ If anything, the play's hero is a little less eloquent and stumbles even more than his loquacious fellows. Der Schwierige as a whole - or rather, as a text - is discreet in an analogous sense: it constitutes a move from a literary language that would signal unique individuality to a more "alltägliche Redeweise." ${ }^{63}$ The play is written in a shared language of colloquial conversation; in this way it is discreet.

Der Schwierige is a comedy of society. Society is defined, quite strictly, in terms of the discordant intentions of multiple individuals and the unintended consequences of their interactions. Much of the comedy derives from the disconnections between actions and outcomes. The misanthropic character may critique this condition, and yet by rejecting society as a futile spectacle of confusions, he shows that he too conceptualizes agency as the (failed) realization of intentions in social interaction. Presenting comedic or critical accounts of society, the play nonetheless does not endorse some community held together by "tight, harmonious, infrangible bonds." ${ }^{64}$ Rather, the discreet community that appears in the play takes place in a society of distant, discrete individuals, as the 
unexpected and always ephemeral moment of sympathy. If there is an ideal, it is perhaps the conversation, in which one has to give up one's resolute intentions, remain open to others, and even embrace confusion as the stuff of living with others. This conversation is not a remedy against alienation.

\footnotetext{
${ }^{1}$ For statements regarding the play's place in the German canon, see Michael Hofmann, The Colour of His Eyes, in: London Review of Books, 21 March 2009, p. 21-2; Mathias Mayer, Hugo von Hofmannsthal, Stuttgart: Metzler, 1993, p. 91.

${ }^{2}$ See for instance Alfred Doppler, Wirklichkeit im Spiegel der Sprache, Vienna:

Europaverlag, 1975, p. 67; Robert Vilain, Hofmannsthal's Der Schwierige, in: Peter Hutchinson (ed.), Landmarks in German Comedy, Bern: Peter Lang, 2006, p. 161-78.

${ }^{3}$ See for instance Bernhard Greiner, Die Rede des Unbewussten als Komödie:

Hoffmannsthals Lustspiel Der Schwierige, in: German Quarterly 59, 1986 2, p. 228-51, p. 231.

${ }^{4}$ Hugo von Hofmannsthal, Der Schwierige. Lustspiel in drei Akten, Frankfurt am Main: Fischer, 1993, p. 8 and p. 142.

${ }^{5}$ Jon Elster, Explaining Social Behavior. More Nuts and Bolts for the Social Sciences, Cambridge UK: Cambridge University Press, 2007, p. 303-5.

${ }^{6}$ Hofmannsthal, Der Schwierige (see note 4), p. 13.

${ }^{7}$ Thomas Schelling, Micromotives and Macrobehavior, New York: Norton \& Co., 1978, p. 13.

${ }^{8}$ Roger Norton, The Inception of Hofmannsthal's Der Schwierige. Early Plans and Their Significance, in: PMLA 79, 1964 1, p. 97-103, p. 98.

${ }^{9}$ Charles Taylor, Modern Social Imaginaries, in: Public Culture 14, 2002, p. 91-124, p. 97-101.

${ }^{10}$ Hofmannsthal, Der Schwierige (see footnote 4), p. 43.

${ }^{11}$ Norton, Inception (see note 8), p. 98.

${ }^{12}$ W. E. Yates, Hofmannsthal's Comedies, in: Thomas A. Kovach (ed.), A Companion to the Works of Hugo von Hofmannsthal, Rochester: Camden House, 2002, p. 139-56, p. 151.

${ }^{13}$ Hugo von Hofmannsthal, Reden und Aufsätzen III. 1925-29, Frankfurt am Main: Fischer, 1985, p. 611.

${ }^{14}$ Jon Elster, Making Sense of Marx, Cambridge UK: Cambridge Unversity Press, 1985, p. 100.

${ }^{15}$ See Henri Bergson, Laughter. An Essay on the Meaning of the Comic, trans. Cloudesley Brereton, Fred Rothwell, New York: MacMillan, 1928, p. 4-5; Elder Olsen, The Theory of Comedy, Bloomington: Indiana University Press, 1968, p. 78. In his recent
} 
book on tragedy, Christoph Menke also states that comedies typically present "how intentions miscarry." See Christoph Menke, Tragic Play. Irony and Theater from Sophocles to Beckett, trans. James Phillips, New York: Columbia University Press, 2009, p. 111.

${ }^{16}$ Peter Szondi, Theorie des modernen Dramas (1880-1950), Frankfurt am Main: Suhrkamp, 1963, p. 89.

${ }^{17}$ Wolf Wucherpfennig, Der Schwierige und der Menschenfeind. Zur Auffassung des Individuums bei Molière und Hofmannsthal, in: Colloquia germanica 3, 1969, p. 269301, p. 285.

${ }^{18}$ Maximilian Bergengruen, "Mystik der Nerven." Neurasthenie, Zerstreutheit und die Metaphysik des Willens in Hofmannsthals Der Schwierige, in: Deutsche Vierteljahresschrift für Literaturwissenschaft und Geistesgeschichte 80, 2006 2, p. 212 44, p. 238.

${ }^{19}$ Mladen Dolmar provides the following reason for people behave discreetly: "Es gibt Dinge, die ihren Wert nur dann behalten, wenn sie unausgesprochen verstanden und angenommen werden, die durch Aussprechen ruiniert würden." To be discreet is to know when to leave things unsaid. See Mladen Dolmar, Die Kunst des Ungesagten, in: Tumult 33, 2009, p. 55-64, p. 55.

${ }^{20}$ Hofmannsthal, Der Schwierige (see note 4), p. 62.

${ }^{21}$ Hofmannsthal, Der Schwierige (see note 4), p. 36 and p. 38.

${ }^{22}$ Hofmannsthal, Der Schwierige (see note 4), p. 93

${ }^{23}$ W. E. Yates, Der Schwierige. The Comedy of Discretion, Modern Austrian Literature 10, 1977 1, p. 1-17, p. 11.

${ }^{24}$ Hofmannsthal, Der Schwierige (see note 4), p. 142.

${ }^{25}$ Dorrit Cohn, The Misanthrope: Molière and Hofmannsthal, arcadia 3, 1968 3, p. 292-

8; Hans-Robert Jauss, The Paradox of the Misanthrope, trans. Sharon Larisch, Comparative Literature 35, 1983 4, p. 305-322.

${ }^{26}$ Hofmannsthal, Der Schwierige (see note 4), p. 142.

${ }^{27}$ Jauss, Misanthrope (see note 25), p. 321.

${ }^{28}$ See Lawrence E. Klein, Politeness, in: Alan Charles Kors (ed.), Encyclopedia of the Enlightenment, vol. 3, Oxford: Oxford University Press, 2003, p. 309-14.

${ }^{29}$ See Christoph Strosetski, Konversation. Ein Kapitel gesellschaftlicher und literarischer Pragmatik im Frankreich des 17. Jahrhunderts, Frankfurt am Main: Peter Lang, 1978, p. 22-4.

${ }^{30}$ Hofmannsthal, Der Schwierige (see note 4), p. 64-5.

${ }^{31}$ Doppler, Wirklichkeit (see note 2), p. 74.

${ }^{32}$ Lorelle Raihala, Choosing Convention: Schnitzler's Comtesse Mitzi and Hofmannthal's Der Schwierige, in: German Quarterly 67, 1994 1, p. 6-15.

33 "Eine Lustspiel-Szene, welche im Leben vorkommt. - Jemand denkst sich eine geistreiche Meinung über ein Thema aus, um sie in einer Gesellschaft vorzutragen. Nun würde man im Lustspiel anhören und ansehen, wie er mit allen Segeln an den Punkt zu kommen und die Gesellschaft dort einzuschiffen sucht, wo er seine Bemerkung machen kann: wie er fortwährend die Unterhaltung nach einem Ziele schiebt, gelegentlich die 
Richtung verliert, sie wiedergewinnt, endlich den Augenblick erreicht: fast versagt ihm der Atem - und da nimmt ihm einer aus der Gesellschaft die Bemerkung vom Munde weg. Was wird er tun? Seiner eigenen Meinung opponieren? See Friedrich Nietzsche, Menschliches, Allzu-Menschliches. Ein Buch für freie Geister, Frankfurt am Main: Insel, 1982, p. 214-5.

${ }^{34}$ Bergengruen, Neurasthenie (see note 18), p. 233.

${ }^{35}$ Jean-Luc Nancy, The Inoperative Community, ed. Peter Connor, trans. Peter Connor et al, Minneapolis: University of Minnesota Press, 1991, p. 4.

${ }^{36}$ Hofmannsthal, Der Schwierige (see note 4), p. 98.

${ }^{37}$ Sheldon Wolin, Politics and Vision: Continuity and Innovation in Western Political Thought, Princeton: Princeton University Press, 2004, p. 314.

${ }^{38}$ Emil Staiger, Hugo von Hofmannsthal: Der Schwierige, in: Sibylle Bauer (ed.), Hugo von Hofmannsthal, Darmstadt: Wissenschaftliche Buchgesellschaft, 1968, p. 402-33, p. 425.

${ }^{39}$ Ernst Robert Curtius, Hofmannsthal, George, and Calderón, in: Die Wandlung 2, 1947 5, p. 401-23, p. 407.

${ }^{40}$ Vilain, Der Schwierige (see note 2), p. 176.

${ }^{41}$ Yates, Hofmannsthal's Comedies, (see note 12), p. 142.

${ }^{42}$ John R. P. McKenzie, "Wahrhaft das Sakrament": Hofmannsthal's Der Schwierige and the Sacrament of Matrimony, in: Modern Language Review 96, 2001 2, p. 409-19.

${ }^{43}$ Wolfram Mauser, Hugo von Hofmannsthal. Konfliktbewältigung und Werkstruktur. Eine psychosoziologische Interpretation, Munich: Wilhelm Fink, 1977, p. 152.

${ }^{44}$ Hofmannsthal, Der Schwierige (see note 4), p. 103.

${ }^{45}$ Hofmannsthal, Der Schwierige (see note 4), p. 104.

${ }^{46}$ Maurice Blanchot, The Unavowable Community, trans. Pierre Joris, Station Hill: Barrytown, 1988, p. 7.

${ }^{47}$ Cohn, The Misanthrope (see note 25), p. 298.

${ }^{48}$ Cohn, The Misanthrope (see note 25), p. 298.

${ }^{49}$ Northrop Frye, Anatomy of Criticism. Four Essays, Princeton: Princeton University Press, 1957, p. 163.

${ }^{50}$ Lynne Truss, Talk to the Hand. The Utter Bloody Rudeness of the World Today, or Six Good Reasons to Stay Home and Bolt the Door, New York: Gotham, 2005, p. 14.

${ }^{51}$ Niklas Luhmann, Gesellschaftsstruktur und Semantik: Studien zur Wissenssoziologie der modernen Gesellschaft, Frankfurt am Main: Suhrkamp, 1993, p. 139.

${ }^{52}$ Vilain, Hofmannsthal's Der Schwierige, (see note 2), p. 173.

${ }^{53}$ Dorothee Kimmich and Wolfgang Matzat, Einleitung, in: Dorothee

Kimmich, Wolfgang Matzat (ed.), Der gepflegte Umgang. Interkulturelle Aspekte der

Höflichkeit in Literatur und Sprache, Bielefeld: transcript, 2008, p. 8-9.

${ }^{54}$ Hugo von Hofmannsthal, Der Schwierige (see footnote 4), p. 70.

55 Truss, Talk (see note 50), p. 61. 
${ }^{56}$ Karmen MacKendrick, Make It Look Easy: Thoughts on Social Grace, in: Ron Scapp, Brian Seitz (ed.), Etiquette. Reflections on Contemporary Comportment, Albany: SUNY University Press, 2007, p. 202.

${ }^{57}$ Carl E. Schorske, Fin-de-Siècle Vienna. Politics and Culture, New York: Vintage, 1961, p. 21.

${ }^{58}$ McKenzie, Wahrhaft (see note 42), p. 409.

${ }^{59}$ Benjamin Bennett, Hugo von Hofmannsthal. The Theatres of Consciousness, Cambridge UK: Cambridge University Press, 1988, p. 162.

${ }^{60}$ Hugo von Hofmannsthal, Leopold Andrian, Briefwechsel, Frankfurt am Main: Fischer, 1968, p. 253.

${ }^{61}$ Strosetski, Konversation (see note 29), p. 41-2.

${ }^{62}$ Hofmannsthal, Der Schwierige (see note 4), p. 35-6 and p. 68.

${ }^{63}$ Wilhelm Emrich, Hofmannsthals Lustspiel Der Schwierige, in: Sibylle Bauer (ed.), Hugo von Hofmannsthal, Darmstadt: Wissenschaftliche Buchgesellschaft, 1968, p. 435. ${ }^{64}$ Nancy, Community (see note 35), p. 9. 